\title{
Analisis Studi Kelayakan Bisnis Fashion Muslimah "Galery Amanah" menggunakan Pendekatan Business Process Management (BPM)
}

\author{
Anggun Nur Azizah ${ }^{1}$, Iskandar Zulkarnaen*2, Solihin ${ }^{3}$, Paduloh ${ }^{4}$ \\ 1,2,3,4 Teknik Industri Fakultas Teknik, Universitas Bhayangkara Jakarta \\ e-mail: ${ }^{1}$ anggunna98@gmail.com, $* 2$ iskandar.zulkarnaen@dsn.ubharajava.ac.id, \\ 35solihin@dsn.ubharajaya.ac.id, ${ }^{4}$ paduloh@dsn.ubharajaya.ac.id
}

\begin{abstract}
"Galery Amanah" is a business engaged in the women's Muslim clothing sector that has the concept of shar'i, simple and comfortable. This study aims to know business feasibility studies in terms of several aspects including market and marketing aspects, competitor aspects, legal aspects, technical/production aspects and financial aspects. In addition to reviewing some of these aspects, the existing discussion uses the Business Process Management (BPM) approach. BPM allows companies to find out and assess whether the business processes that are now running effectively and efficiently and to make improvements if there are discrepancies. From the results of the study it was concluded that various aspects of the "Galery Amanah" are feasible to run, and from the results of the calculation of profit/loss the Amanah Gallery can generate a minimum profit is Rp21.000.000/year. While the results of the Business Process Management (BPM) approach obtained by several additional business processes (to-be models) from the results of the analysis and simplification.
\end{abstract}

Keywords: Business Feasibility Study, Business Processes, Business Process Management (BPM), Business Process Management Notation (BPMN).

\section{PENDAHULUAN}

Fashion merupakan sebuah kebutuhan dan suatu hal yang digemari oleh kaum wanita. Wanita sebagai pengguna fashion beranggapan bahwa fashion dapat menunjukan identitas diri, style dan menambah kepercayaan diri. Pertumbuhan bisnis fashion muslimah di Indonesia mulai meningkat pada tahun 2013. Berdasarkan data pada web gbgindonesia, fashion muslim untuk wanita tiap tahunnya mengalami kenaikan yang signifikan, yaitu: $49.8 \%$ pada tahun $2014,50,55 \%$ pada tahun 2015, 52,5\% pada tahun 2016, dan diperkirakan pada tahun 2020 mencapai angka $60 \%$. Melihat peluang bisnis fashion muslimah yang begitu besar dan kebutuhan sandang setiap individu semakin meningkat menjadikan bisnis fashion digemari oleh para peminat usaha.

Galery Amanah merupakan suatu usaha yang bergerak di sektor fashion Muslimah baru bergerak selama enam bulan. Produk yang ditawarkan adalah gamis, abaya, hijab syar'i, inner hijab, handsock dan produk fashion wanita muslim lainnya. Konsep produk yang ditawarkan Galery Amanah adalah shari'a, simple and comfortable, konsep tersebut dibawa untuk memenuhi kebutuhan muslimah yang memiliki pandangan spiritual wajibnya berhjab syar'i. Target pasar Galery Amanah adalah muslimah usia 15-34 tahun untuk semua kalangan di lapisan masyarakat. Galery Amanah direncanakan akan memiliki gudang penyimpanan di Bekasi, dan akan memasarkan produknya secara online menggunakan media seperti Website, Facebook, Instagram, dan platform $e$ commerce yang sedang banyak peminatnya seperti shopee.

Pangsa pasar bisnis fashion muslimah di Indonesia cukup besar dikarenakan mayoritas penduduknya adalah muslim dan menggunakan hijab untuk kaum wanita. Berikut data penduduk Kota Bekasi berdasarkan jenis kelamin, agama islam dan kategori umur dapat dilihat pada Gambar 1.

Kota Bekasi memiliki jumlah penduduk wanita muslimah mencapai 1 juta jiwa. Berdasarkan Data BPS (2020) dalam publikasinya yaitu Kota Bekasi Dalam Angka 2020 diperkirakan jumlah penduduk di Kota 
Bekasi adalah sebanyak 2,45 juta jiwa dengan jumlah penduduk beragama islam sekitar $88 \%$ atau sebanyak 2.166.132 jiwa dengan angka sex ratio adalah 101,83 yang artinya terdapat 101-102 penduduk laki laki dalam setiap 100 penduduk perempuan.

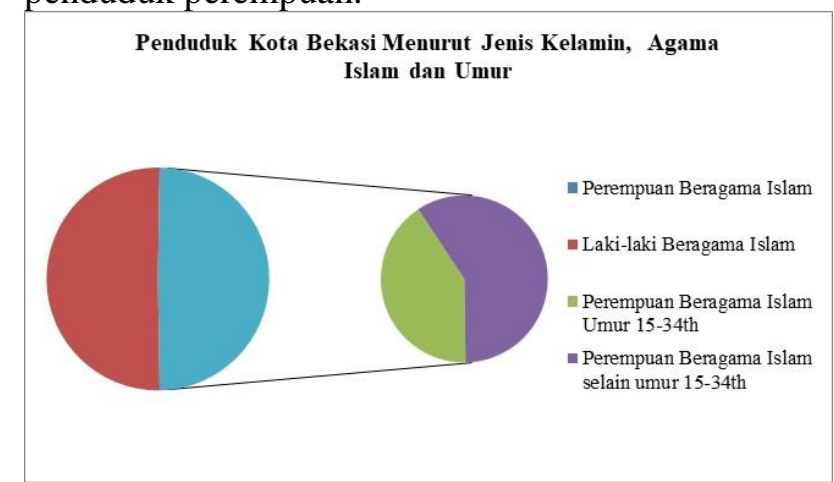

(Sumber: Proyeksi data BPS 2020)

Gambar 1 Penduduk Kota Bekasi Menurut Jenis Kelamin, Agama dan Umur

Dari data tersebut diperkirakan jumlah penduduk di Kota Bekasi yang berjenis kelamin perempuan dan beragama islam adalah sebanyak 1.072 .350 jiwa. Dengan demikian jika menggunakan asumsi 40,95\% adalah pasar potensial yaitu muslimah dengan rentang umur 15-34 tahun, maka didapat pasar potensial fashion muslimah syar'i di Kota Bekasi adalah sekitar 439.127 jiwa. Asumsi $40,95 \%$ diambil dari jumlah presentase penduduk di Kota Bekasi berjenis kelamin perempuan, beragama islam dan dengan rentang umur 15-34 tahun pada data sensus penduduk 2010. Dari angka 439.127 ini, peneliti menetapkan $10 \%$ adalah pasar potensial pakaian syar'i berdasarkan segmentasi industri fashion muslimah di Indonesia. Dengan demikian bisa didapatkan pasar potensial pakaian syar'i adalah sekitar 43.913 jiwa. "Galery Amanah" menetapkan target minimal $2 \%$ dari pasar potensial tersebut merupakan permintaan potensial yang belum terlayani oleh pesaing yaitu sekitar 878 orang. Dari perhitungan tersebut maka target permintaan potensial yang harus dicapai oleh "Galery Amanah" adalah minimal berjumlah 832 orang. Penggunaan angka $10 \%$ ini merupakan asumsi dari perkiraan muslimah yang menggunakan hijab syar'i menurut gbgindonesia dalam artikelnya yang berjudul "Indonesia Aiming to be the Islamic Fashion Capital by 2020" (2017), sedangkan angka 2\% diambil berdasarkan asumsi peneliti dengan mempertimbangkan jumlah pesaing yang ada, luas wilayah, daya beli masyarakat dan promosi yang dilakukan oleh perusahaan.

Menurut hasil observasi yang dilakukan oleh "Galery Amanah" melalui media online dan masyarakat di lingkungan owner "Galery Amanah" pada akhir tahun 2019 mengenai minat masyarakat dalam membeli pakaian muslim, menunjukan bahwa muslimah minimal membeli satu set pakaian baru dalam satu tahun, dan setiap minggunya minimal dapat menggunakan tiga pakaian yang berbeda. Dari kondisi ini dapat disimpulkan bahwa peluang pasar bisnis fashion muslimah berpotensi berkembang pesat seiring dengan meningkatnya kebutuhan konsumen, sehingga bisnis ini memiliki potensi untuk berkembang dan memberi keuntungan bagi pelaku usaha. Peluang "Galery Amanah" mencapai target yang ingin dicapai bisa diraih jika perusahaan dapat memahami kondisi pasar yang ada,

Dalam menjalankan operasional perusahaan, ada target yang harus dicapai sebuah perusahaan yaitu sebuah keuntungan atau laba. Laba dalam penjualan 1 set pakaian muslimah saat ini adalah sebesar Rp40.000/set dengan modal yang diperlukan adalah sekitar Rp188.000/set. Dengan ini dapat diketahui profit margin saat ini adalah sebesar $21 \%$, sedangkan perusahaan memiliki target profit margin yang ingin dicapai adalah sebesar $30 \%$ dengan melihat kualitas produk "Galery Amanah" yang baik. Dari penjabaran tersebut dapat diketahui "Galery Amanah" ingin meningkatkan profit marginnya dari $21 \%$ menjadi $30 \%$. Keinginan perusahaan untuk mencapai target yang bisa saja dipenuhi dengan melakukan analisis kelayakan investasi.

Dalam melakukan studi kelayakan ini peneliti juga menggabungkan metode studi kelayakan bisnis dengan manajemen proses bisnis atau biasa dikenal Business Process Management (BPM) untuk mendapatkan hasil penelitan yang lebih sempurna dan terarah. Penelitian ini merupakan studi kelayakan bisnis yang digunakan untuk meminimalisir terjadinya kegagalan dan memberikan keuntungan bagi "Galery Amanah". BPM adalah suatu pendekatan untuk mencapai tujuan bisnis dengan mengkoordinasi prosesproses akhir dari perusahaan, menciptakan best practices, dan perangkat lunak perlengkapan seperti di dalam suatu sistem manajemen 


\section{Analisis Studi Kelayakan Bisnis Fashion Muslimah "Galery Amanah"}

menggunakan Pendekatan Business Process Management (BPM)

proses bisnis, untuk mendeskripsikan, peneliti, dan menambahkan efisiensi dari proses-proses terhadap goal bisnis (Lawler, 2013). Sebuah proses bisnis seharusnya memiliki tujuan untuk mengefisiensikan, mengefektifkan dan memudahkan proses-proses di dalamnya. Sehingganya proses bisnis perlu dikelola dengan baik.

Tujuan dari penelitian ini adalah Mengetahui hasil uji kelayakan bisnis fashion muslimah "Galery Amanah" agar dapat dijalankan, mengetahui hasil analisis kelayakan bisnis fashion muslimah "Galery Amanah" dari aspek pasar dan pemasaran, mengetahui hasil analisis kelayakan bisnis fashion muslimah "Galery Amanah" dari aspek pesaing, mengetahui hasil analisis kelayakan bisnis fashion muslimah "Galery Amanah" dari aspek hukum, mengetahui hasil analisis kelayakan bisnis fashion muslimah "Galery Amanah" dari aspek teknis/produksi, mengetahui hasil analisis kelayakan bisnis fashion muslimah "Galery Amanah" dari aspek finansial, mengetahui hasil analisis kelayakan bisnis fashion muslimah "Galery Amanah" dari pendekatan Business Process Management (BPM), mengetahui alternatif apa yang akan dilakukan jika hasil analisis kelayakan bisnis fashion muslimah "Galery Amanah" tidak layak.

\section{Studi Kelayakan Bisnis}

Studi kelayakan bisnis (businesses feasibility study) atau disebut analisis proyek bisnis merupakan suatu penelitian tentang layak tidaknya suatu bisnis dilakukan/dijalankan dengan menguntungkan pelaku bisnis secara terus-menerus. Studi ini membahas berbagai konsep dasar yang berkaitan dengan proses pengambilan keputusan dan pemilihan proyek bisnis agar mampu memberikan keuntungan sepanjang masa dan meminimalisir adanya kerugian. Dalam studi ini, pertimbangan-pertimbangan secara teknis dan finansial sangat penting karena akan dijadikan dasar dari implementasi kegiatan usaha (Waluyo, 2010). Studi kelayakan bisnis adalah penelitian yang menyangkut berbagai aspek seperti aspek hukum, sosial ekonomi, aspek lingkungan, aspek budaya, aspek pasar dan pemasaran, aspek teknis sampai dengan aspek manajemen dan finansial, dimana aspek tersebut digunakan untuk dasar penelitian studi kelayakan dan hasilnya digunakan untuk mengambil keputusan apakah suatu proyek atau bisnis yang diteliti dapat dikerjakan atau ditunda dan bahkan tidak dijalankan sama sekali. Mengingat bahwa nantinya akan terjadi kondisi ketidakpastian, maka diperlukan pertimbangan-pertimbangan tertentu dalam memulai suatu bisnis, dimana dasar dari pertimbangan-pertimbangan tersebut dapat diperoleh melalui studi kelayakan bisnis, sehingga hasil daripada studi tersebut digunakan untuk memutuskan (Sulastri, 2016).

Beberapa pihak yang memerlukan/ berkepentingan dengan studi kelayakan usaha/bisnia, diantaranya yaitu:

1. Pihak Wirausaha (Pemilik Perusahaan)

a. Dalam memulai bisnis/usaha atau mengembangkan bisnis/usaha diperlukan pengorbanan yang cukup besar dan selalu dihadapkan pada ketidakpastian.

b. Studi kelayakan bisnis sangat penting, agar pelaku wirausaha bisa meminimalisasi kegagalan dan memberikan keuntungan sepanjang waktu.

c. Studi kelayakan bisnis berfungsi sebagai laporan, pedoman dan sebagai bahan pertimbangan untuk merintis usaha, mengembangkan usaha, melakukan investasi baru, sehingga bisnis yang akan dilakukan meyakinkan baik bagi pelaku wirausaha maupun bagi semua pihak yang berkepentingan.

2. Pihak Investor dan Penyandang Dana

Bagi investor/penyandang dana, studi kelayakan usaha penting untuk memilih jenis investasi yang paling menguntungkan dan sebagai jaminan atas modal yang ditanamkan. Apakah investasi yang dilakukan memberikan jaminan pengembalian investasi (return of invesment) yang memadai atau tidak. Bagi investor, studi kelayakan bisnis sering digunakan sebagai bahan pertimbangan layak tidaknya investasi dilakukan.

3. Pihak Masyarakat dan Pemerintah

Bagi masyarakat, studi kelayakan bisnis sangat diperlukan sebagai bahan kajian apakah usaha yang sedang didirikan atau dikembangkan bermanfaat bagi masyarakat sekitarnya ataupun pemerintah. 


\section{Segmen Pasar}

Pasar sasaran adalah mengevaluasi keaktifan setiap satu segmen pasar atau lebih untuk dilayani. Menetapkan pasar sasaran dengan cara mengembangkan ukuran dan daya tarik segmen pasar, kemudian memilih segmen sasaran yang diinginkan (Jakfar, 2010). Kegiatan menetapkan pasar diantaranya meliputi:

1. Evaluasi segmen pasar

a. Ukuran dan pertumbuhan segmen seperti data tentang penjualan terakhir (dalam rupiah), proyeksi laju pertumbuhan dan margin laba dari setiap segmen.

b. Struktural segmen yang menarik dari segi profitabilitas/keuntungan.

c. Sasaran dan sumber daya perusahaan.

2. Memilih segmen, yaitu menentukan satu atau lebih segmen yang memiliki nilai tinggi bagi perusahaan, menentukan segmen mana dan berapa banyak yang dapat dilayani.

a. Pemasaran serbasama, melayani semua pasar dan tawaran pasar dalam arti tidak ada perbedaan.Contohnya permen yang bisa ditujukan untuk semua orang.

b. Pemasaran serbaaneka, merancang tawaran untuk semua pendapatan, tujuan atau kepribadian. Contohnya beda desain untuk industri mobil.

c. Pemasaran terpadu, untuk sumber daya manusia yang terbatas dengan kesamaan produk .

\section{Aspek Pemasaran}

Pemasaran adalah semua aktivitas dunia usaha yang berhubungan dengan barang dan jasa dari saat barang diproduksi sampai dikonsumsi, termasuk didalamnya tindakan pembelian, penjualan, penyelenggaraan iklan, pemisahan menurut nilai, pengangkutan, pergudangan/penyimpanan barang, pemfungsian informasi pasar, serta pembiayaan/permodalan. Pemasaran merupakan salah satu kunci dari keberhasilan sebuah bisnis/usaha. Usaha yang mampu menguasai pasar dan pemasaran berarti akan memperoleh laba yang menjamin keberlanjutan usahanya (Danang, 2012).

Menurut Kottler (2007), pemasaran merupakan suatu proses sosial dan manajerial dimana individu dan kelompok memperoleh apa yang mereka butuhkan dan inginkan dengan cara menukarkan produk atau nilai dengan pihak lain. Aspek ini dilakukan untuk menilai apakah perusahaan yang akan melakukan investasi ditinjau dari segi pasar dan pemasaran memilki peluang pasar yang akan diinginkan atau tidak (Ningtyas et al., 2018)

Pentingnya peranan pemasaran dalam menentukan kelanjutan usaha suatu perusahaan, membuat banyak perusahan dalam manajemennya menempatkan posisi pemasaran paling depan. Pemasar harus tahu dan mengerti terlebih dahulu mengenai pasar yang akan dimasukinya, seperti: ada tidak pasarnya, seberapa besarnya pasar yang ada, potensi pasar dan tingkat persaingan yang ada. termasuk besarnya market share yang akan direbut dan market share pesaing yang akan dianalisa.

\section{Rencana Bisnis (Business Plan)}

Rencana bisnis (business plan) adalah dokumen tertulis yang mendeskripsikan mengenai masa depan bisnis yang akan dimulai. Rencana ini meliputi apa, bagaimana, kapan, siapa dan mengapa sebuah bisnis dijalankan. Rencana bisnis pada umumnya terdiri dari :

1. Tujuan sebuah bisnis/usaha

2. Strategi yang digunakan untuk mencapainya tujuan bisnis

3. Masalah potensial yang akan dihadapi dan cara mengatasinya

4. Struktur organisasi (termasuk jabatan dan tanggung jawab)

5. Jadwal waktu pelaksanaan pekerjaan

6. Modal yang diperlukan untuk membiayai bisnis.

Studi kelayakan bisnis mempunyai keterkaitan yang erat dengan rencana bisnis. Sebuah ide bisnis yang telah dilakukan studi kelayakan dan dinyatakan layak dijalankan maka langkah selanjutnya adalah membuat rencana bisnis. Jika rencana bisnis dapat dilaksanakan maka dilakukanlah pelaksanaan bisnis. Jika ide bisnis tidak layak atau tidak dapat dilaksanakan maka kembalikan proposal bisnis yang ditunda/ditolak, lalu lakukan kembali studi kelayakan bisnis dengan merubah ide bisnis atau mengevaluasi kembali ide bisnis (Setriani, 2013). 


\section{Business Process Management (BPM)}

Proses bisnis adalah organisasi yang mencakup manusia, material, energi, alat dan prosedur pada suatu perencanaan sebuah aktivitas untuk menghasilkan suatu hasil akhir yang mendetail (Nugraha et al., 2019). Proses bisnis dapat didefinisikan sebagai kegiatan atau serangkaian kegiatan yang berkontribusi terhadap realisasi produk atau layanan akhir baik dengan menambahkan nilai pada input organisasi baik atau dengan berkontribusi pada pengembangan optimal kegiatan. Proses bisnis mewakili serangkaian aktivitas terstruktur dan terukur yang dirancang untuk menghasilkan output spesifik untuk pelanggan atau pasar tertentu. Ini menyiratkan penekanan kuat pada bagaimana pekerjaan dilakukan dalam suatu organisasi, berbeda dengan penekanan fokus produk.

Business Process Management (BPM) atau manajemen proses bisnis merupakan seni dan ilmu untuk melihat bagaimana pekerjaan dijalankan dalam organisasi untuk menjamin keluaran yang konsisten serta untuk mengambil keuntungan dari setiap kesempatan. BPM juga merupakan sebuah konsep, metode dan teknik yang digunakan untuk membantu perancangan, administrasi, konfigurasi, pelaksanaan serta analisa proses bisnis. Dasar dari BPM adalah representasi dari proses bisnis dengan aktivitas serta batasannya (Dumas et al., 2013).

Siklus atau lifecycle Business Process Management (BPM) terdiri dari beberapa fase yang saling berhubungan. Berikut siklus hidup BPM dapat dilihat pada Gambar 2.

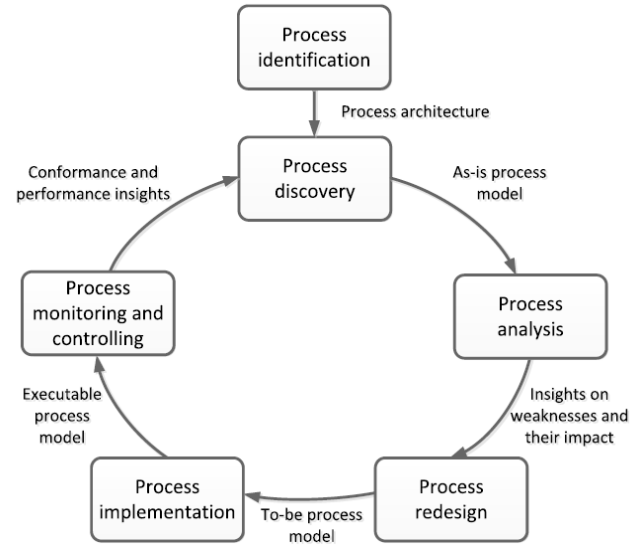

Sumber: Dumas, 2013

Gambar 2 Lifecycle BPM

\section{METODE PENELITIAN}

Pengumpulan Data

$\begin{array}{clll}\text { Data } & \text { yang } & \text { dikumpulkan } & \text { dalam } \\ \text { penelitian } & \text { ini } & \text { berdasarkan } & \text { teknik }\end{array}$ pengumpulanya ada tiga, berikut data-data yang akan dikumpulkan peneliti untuk memenuhi kebutuhan penelitian:

1. Data yang dikumpulkan dalam penelitian ini antara lain yaitu data observasi jumlah pesaing, profil dan bentuk perusahaan pesaing, syarat dan cara memperoleh izin perusahaan dagang, fenomena kebutuhan muslimah akan sandang/pakaian, dan data lain yang diperlukan untuk penelitian ini.

2. Data wawancara yang dibutuhkan antara lain wawancara dengan rowner untuk mengetahui profil perusahaan, strategi yang dilakukan perusahaan, proses produksi dan operasional, kebutuhan dan sumber dana, penentuan biaya, laporan keuangan dan hal lainnya yang berkaitan dengan penelitian kelayakan bisnis ini. Selanjutnya adalah wawancara dengan responden yang merupakan konsumen potensial untuk mengetahui kesesuaian produk "Galery Amanah" dengan kebutuhan konsumen.

3. Data dokumentasi yang dikumpulkan antara lain yaitu jurnal tentang studi kelayakan bisnis dan Business Process Management (BPM), data BPS online mengenai demografi dan kependudukan, data segmentasi industri fashion, seperti buku, majalah, jurnal, artikel, media internet, data bps online, artikel mengenai fashion muslimah di Indonesia.

\section{Pengolahan Data}

Pengolahan data akan ditampilkan ke dalam tabel dan grafik, data yang diolah sesuai aspeknya antara lain: menentukan segmentasi pasar, target pasar dan positioning perusahaan, mengolah data hasil wawancara, uji validitas, pengukuran variabel produk, menentukan perkiraan jumlah pesaing, check list syarat perizinan, menentukan kapasitas produksi dan tanggung jawab para pemangku kepentingan, menghitung keuntungan dan kebutuhan. 


\section{Analisis Data}

Analisis data yang digunakan dalam penelitian ini yaitu diantaranya menggunakan analisis strategi bauran pemasaran 4P (Produk, Price, Place, Promotion), analisis SWOT (Strenght, Weaknes, Oportunity, Threaths), analisis nilai kelayakan investasi (Payback period, Net Present Value, Internal Rate of Return), analisis keuntungan (Break Event Point), analisis Porter Five Forces, analisis $5 \mathrm{~W}+1 \mathrm{H}$ (What, when, who, where, why, how) dan pendekatan menggunakan metode Business Process Management (BPM).

Tahapan pada penelitian ini dapat dilihat pada Gambar 3.

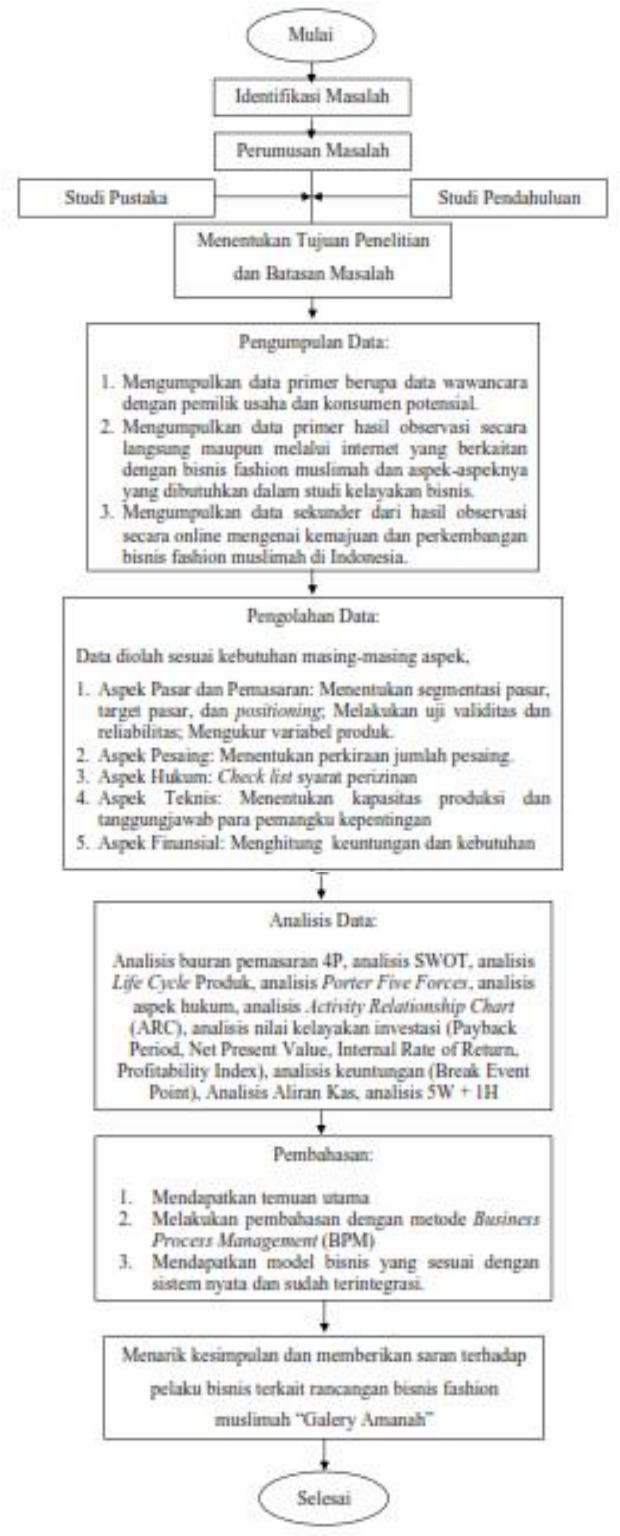

Gambar 3 Tahapan Penelitian

\section{HASIL DAN PEMBAHASAN \\ Business Process Management (BPM)}

Dalam melakukan analisis menggunakan pendekatan Business Process Management (BPM) terdapat siklus (life cycle) dari proses bisnis yang perlu diketahui terlebih dahulu, siklus dalam proses bisnis yang saling berkaitan itu antara lain process identification, process discovery, process analysis, process redesign, setelah process redesign baru akan ada process implementation dan process monitoring and controlling.

Sebelum memasuki tahap pembahasan life cycle Business Process Management (BPM), berikut akan ditampilkan identifikasi bisnis dari hasil analisis pada aspek pasar dan pemasaran penentuan segmentasi pasar, target pasar, positioning dengan memberikan kuesioner kepada masyarakat Kota Bekasi khususnya customer "Galery Amanah" aspek pesaing yang melibatkan para competitorkompetitor baru, industri startup, aspek hukum yakni Surat Izin Usaha Perdagangan dan Tanda daftar Perusahaan, aspek teknis/produksi dan aspek finansial yang berkaitan dengan pemilik, subkontraktor, konsumen, pekerja dan pengembalian modal usaha pada Tabel 1 
Tabel 1 Hasil Analisis Data

\begin{tabular}{|c|c|c|}
\hline No & $\begin{array}{c}\text { Alat } \\
\text { Analisis }\end{array}$ & Hasil Analisis \\
\hline \multicolumn{3}{|r|}{ Aspek Pasar dan Pemasaran } \\
\hline 1 & $\begin{array}{l}\text { Bauran } \\
\text { Pemasaran } \\
\quad 4 \mathrm{P}\end{array}$ & $\begin{array}{l}\text { Product : Produk yang ditawarkan Galery Amanah adalah fashion } \\
\text { muslimah diantaranya adalah gamis, abaya, french khimar, hijab, } \\
\text { french hijab, inner gamis, inner hijab, handsock, bahkan sampai } \\
\text { kaus kaki, } \\
\text { Price : Diperkirakan harga yang ditetapkan adalah dimulai dari } \\
\text { Rp120.000 sampai dengan Rp180.000 untuk gamis, hijab mulai } \\
\text { harga Rp60.000 dan untuk produk lainnya seperti inner hijab dan } \\
\text { gamis, handsock dipastikan berada dibawah harga Rp50.000. } \\
\text { Placement: Toko merupakan toko online, sedangkan gudang } \\
\text { berlokasi di Bekasi. } \\
\text { Promotion : Beberapa strategi yang dapat dilakukan yaitu } \\
\text { periklanan, penjualan personal, promosi penjualan, promosi melalui } \\
\text { seller. }\end{array}$ \\
\hline 2 & SWOT & $\begin{array}{l}\text { Alternatif strategi yang didapatkan dari hasil analisis SWOT antara } \\
\text { lain: } \\
\text { 1. Memperluas daerah pemasaran } \\
\text { 2. Melakukan banyak strategi promosi yang menarik } \\
\text { 3. Membuat desain produk yang menarik sesuai konsep } \\
\text { 4. Melakukan analisis pasar agar PLC (Product Life Cycle) lebih } \\
\text { lama dan stabil } \\
\text { 5. Menentukan strategi bersaing } \\
\text { 6. Melakukan analisis pesaing agar dapat mengetahui kelemahan } \\
\text { pesaing } \\
\text { 7. Meminimalkan biaya produksi tetapi tidak menurunkan kualitas } \\
\text { produk dengan menentukan pilihan produksi yang terbaik dan } \\
\text { menguntungkan }\end{array}$ \\
\hline 3 & $\begin{array}{l}\text { Life Cycle } \\
\text { Produk }\end{array}$ & $\begin{array}{l}\text { Dari hasil analisis dan identifiasi pada PLC, didapat beberapa } \\
\text { strategi baru yang bisa digunakan pada tiap fase siklus diantaranya } \\
\text { yaitu: rapid penetration strategy, branding, membuat varian/model } \\
\text { baru dan inovasi lain, modifikasi pasar dan produk, dan lain-lain. }\end{array}$ \\
\hline \multicolumn{3}{|r|}{$\begin{array}{c}\text { Aspek Pesaing } \\
\end{array}$} \\
\hline 1 & $\begin{array}{c}\text { Porter Five } \\
\text { Force }\end{array}$ & $\begin{array}{l}\text { Berdasarkan hasil analisis Porter Five Force didapatkan hasil } \\
\text { bahwa persaingan perusahaan bisnis fashion muslimah cenderung } \\
\text { tinggi pada ancaman persaingan antar perusahaan sejenis, ancaman } \\
\text { pendatang baru, dan kekuatan tawar menawar pembeli, maka dari } \\
\text { itu diperlukan strategi bersaing antara lain yaitu market } \\
\text { development, differentiation, cost leadership, innovation, dan } \\
\text { alliance. }\end{array}$ \\
\hline \multicolumn{3}{|r|}{$\begin{array}{c}\text { Aspek Hukum } \\
\end{array}$} \\
\hline 1 & $\begin{array}{l}\text { Analisis } \\
\text { Keadaan }\end{array}$ & $\begin{array}{l}\text { Pada aspek hukum, pemilik hanya harus membuat NPWP dan } \\
\text { Surat keterangan domisili usahanya untuk memenuhi persyaratan } \\
\text { pengajuan SIUP, TDP, dan PSME. }\end{array}$ \\
\hline
\end{tabular}




\begin{tabular}{|c|c|c|}
\hline \multicolumn{3}{|r|}{ Aspek Teknis/Produksi } \\
\hline 1 & $\begin{array}{l}\text { Analisis } \\
\text { Keadaaan }\end{array}$ & $\begin{array}{l}\text { Pada aspek teknis/produksi, penentuan lokasi yang ditetapkan } \\
\text { adalah toko berupa toko online dan gudang yang berlokasi di } \\
\text { Bekasi. Gudang memiliki luas } 3 \times 3 \text { m dengan menerapkan layout } \\
\text { bentuk bebas menyesuaikan dengan kategori produk dan kebutuhan. } \\
\text { Dalam proses produksinya, Galery Amanah melakukan kerja sama } \\
\text { dengan jasa konveksi, selanjutnya saat produk sudah selesai } \\
\text { produksi akan di pasarkan melalui e-commerce. Dalam proses } \\
\text { produksinya "Galery Amanah" melakukan dua kebijakan kapan } \\
\text { produk akan di produksi kembali sesuai dengan periode dan analisis } \\
\text { hasil penjualan. }\end{array}$ \\
\hline \multicolumn{3}{|r|}{ Aspek Finansial } \\
\hline 1 & $\begin{array}{l}\text { Analisis } \\
\text { Nilai } \\
\text { Investasi }\end{array}$ & $\begin{array}{l}\text { Hasil perhitungan kelayakan investasi yang meliputi PP, NPV, IRR, } \\
\text { dan PI menunjukkan bahwa usaha Galery Amansh layak untuk } \\
\text { dijalankan, karena masing-masing perhitungan memenuhi kriteria } \\
\text { investasi. Payback Period yang dihasilkan yaitu } 8 \text { bulan, lebih } \\
\text { pendek dari umur investasi yaitu } 12 \text { bulan, nilai NPV sebesar } \\
18.507 .692 \text { dimana lebih dari nol, IRR yang diperoleh yaitu } 14,6 \% \\
\text { dan lebih besar dari tingkat suku bunga yaitu } 4 \% \text {, serta hasil } \\
\text { perhitungan PI menunjukkan angka 1,47> }>\text {, berarti usaha Galery } \\
\text { Amanah layak dijalankan. }\end{array}$ \\
\hline 2 & $\begin{array}{c}\text { Analisis } \\
\text { BEP }\end{array}$ & $\begin{array}{l}\text { Berdasarkan pada perhitungan BEP per unit, diketahui bahwa } \\
\text { Galery Amanah perlu menjual sebanyak } 486 \text { unit pada tahun } \\
\text { pertama dan } 480 \text { unit pada tahun kedua untuk mencapai titik } \\
\text { impasnya. }\end{array}$ \\
\hline 3 & $\begin{array}{l}\text { Analisis } \\
\text { Cash Flow }\end{array}$ & $\begin{array}{l}\text { Laba yang didapatkan adalah sekitar Rp21.000.000, akan tetapi laba } \\
\text { tersebut tidak mutlak kas perusahaan karena belum dikurangi untuk } \\
\text { gaji pemilik usaha (owner) karena usaha Galery Amanah masuk } \\
\text { dalam usaha perorangan. Tetapi sudah dipastikan dari hasil } \\
\text { perhitungan bahwa usaha bisnis fashion muslimah ini layak } \\
\text { dijalankan dan mendapatkan keuntungan yang besar. }\end{array}$ \\
\hline
\end{tabular}

\section{Proses Identification}

Tahap process identification menjelaskan mengenai tahap mengidentifikasi proses bisnis yang ada di Galery Amanah. Proses ini dilakukan dengan menggunakan acuan APQC PCF (Center, A. P. \& Q, 2006), American Produtivity and Quality Center (APQC) mengajukan suatu kerangka yang dikernal sebagai process classification framework (PCF), kerangka ini berisi taksonomi untuk proses bisnis. Setelah di identifikasi dengan acuan PCF, proses bisnis utama yang dilakukan Galery Amanah yaitu:

1. Develop Vision and Strategy

2. Design and Develop Produkcts and Services

3. Market and Sell Products and Services

4. Manage Customer Services

5. Deliver Products and Services
Dari identifikasi tersebut dibuat beberapa pengelompokan proses yang lebih rinci yaitu proses manajemen, proses penjualan, proses realisasi produk (produksi), proses pembelian dan proses pendukung. Metode yang digunakan pada tahap ini adalah weighted selection approach. Penilaian proses bisnis dengan Weighted Selection approach dapat dilihat pada Tabel 2 . 
Analisis Studi Kelayakan Bisnis Fashion Muslimah “Galery Amanah" menggunakan Pendekatan Business Process Management (BPM)

Tabel 2 Penilaian Proses Bisnis Menggunakan Weighted Selection Approach

\begin{tabular}{|c|c|c|c|c|c|}
\hline \multirow[b]{2}{*}{$\begin{array}{c}\text { Kelom } \\
\text { pok } \\
\text { Proses }\end{array}$} & \multirow[b]{2}{*}{$\begin{array}{l}\text { Nama } \\
\text { Proses } \\
\text { Bisnis }\end{array}$} & \multicolumn{3}{|c|}{ Pengaruh Kepada } & \multirow[t]{2}{*}{$\begin{array}{c}\text { TOT } \\
\text { AL }\end{array}$} \\
\hline & & $\begin{array}{c}\text { Pelan } \\
\text { ggan }\end{array}$ & $\begin{array}{c}\text { Perfor } \\
\text { mansi } \\
\text { Perusa } \\
\text { haan }\end{array}$ & $\begin{array}{c}\text { Bisnis } \\
\text { Perusa } \\
\text { haan }\end{array}$ & \\
\hline \multirow{2}{*}{$\begin{array}{l}\text { Proses } \\
\text { Manaj } \\
\text { emen }\end{array}$} & $\begin{array}{l}\text { Meneri } \\
\text { ma } \\
\text { laporan } \\
\text { bulanan }\end{array}$ & 1 & 2 & 5 & 8 \\
\hline & $\begin{array}{l}\text { Control } \\
\text { ling } \\
\text { per-hari }\end{array}$ & 1 & 3 & 3 & 7 \\
\hline \multirow{2}{*}{$\begin{array}{c}\text { Proses } \\
\text { Penjua } \\
\text { lan }\end{array}$} & $\begin{array}{c}\text { Penang } \\
\text { anan } \\
\text { Order }\end{array}$ & 4 & 3 & 3 & 10 \\
\hline & $\begin{array}{l}\text { Pengiri } \\
\text { man } \\
\text { Order }\end{array}$ & 4 & 3 & 2 & 9 \\
\hline \multirow{4}{*}{$\begin{array}{c}\text { Proses } \\
\text { Produ } \\
\text { ksi }\end{array}$} & $\begin{array}{l}\text { Pembua } \\
\text { tan } \\
\text { Sempel } \\
\text { Produk }\end{array}$ & 2 & 2 & 2 & 6 \\
\hline & $\begin{array}{c}\text { Perenca } \\
\text { naan } \\
\text { Produk } \\
\text { si } \\
\end{array}$ & 2 & 3 & 3 & 8 \\
\hline & $\begin{array}{l}\text { Invento } \\
\text { ry } \\
\text { Control }\end{array}$ & 1 & 2 & 3 & 6 \\
\hline & $\begin{array}{l}\text { Produk } \\
\text { si }\end{array}$ & 5 & 4 & 4 & 13 \\
\hline \multirow{2}{*}{$\begin{array}{c}\text { Proses } \\
\text { Pembe } \\
\text { lian }\end{array}$} & $\begin{array}{c}\text { Pemesa } \\
\text { nan } \\
\text { Bahan } \\
\text { baku }\end{array}$ & 2 & 3 & 3 & 8 \\
\hline & $\begin{array}{c}\text { Pengen } \\
\text { dalian } \\
\text { Bahan } \\
\text { baku }\end{array}$ & 4 & 3 & 3 & 10 \\
\hline \multirow{4}{*}{$\begin{array}{l}\text { Proses } \\
\text { Pendu } \\
\text { kung }\end{array}$} & $\begin{array}{c}\text { Pengars } \\
\text { ipan } \\
\text { perhari }\end{array}$ & 1 & 2 & 2 & 5 \\
\hline & $\begin{array}{c}\text { Penang } \\
\text { anan } \\
\text { Keluha } \\
n \\
\text { Pelangg } \\
\text { an }\end{array}$ & 4 & 2 & 2 & 10 \\
\hline & $\begin{array}{c}\text { Pembua } \\
\text { tan } \\
\text { Lapora } \\
n \\
\text { Keuang } \\
\text { an } \\
\text { Perbula } \\
\text { n }\end{array}$ & 1 & 3 & 4 & 8 \\
\hline & $\begin{array}{c}\text { Mengat } \\
\text { ur } \\
\text { Aliran } \\
\text { Kas }\end{array}$ & 1 & 3 & 3 & 7 \\
\hline
\end{tabular}

Gambar 4. Proses bisnis yang telah dibuat ini kemudian akan didetailkan lagi pada tahap discovery untuk memastikan bahwa seluruh kelompok proses bisnis tercakup didalamnya.

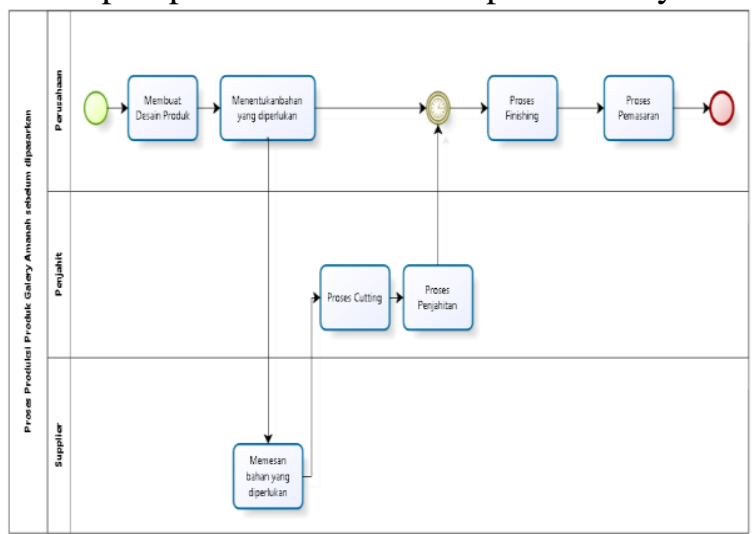

Gambar 4 BPMN Galery Amanah pada Aliran Produksi Pakaian Muslimah

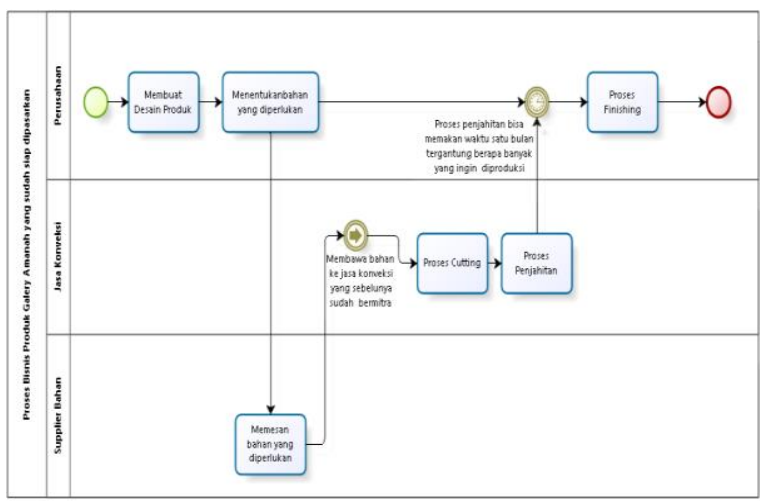

Gambar 5 Model as-is Proses Produksi Galery Amanah

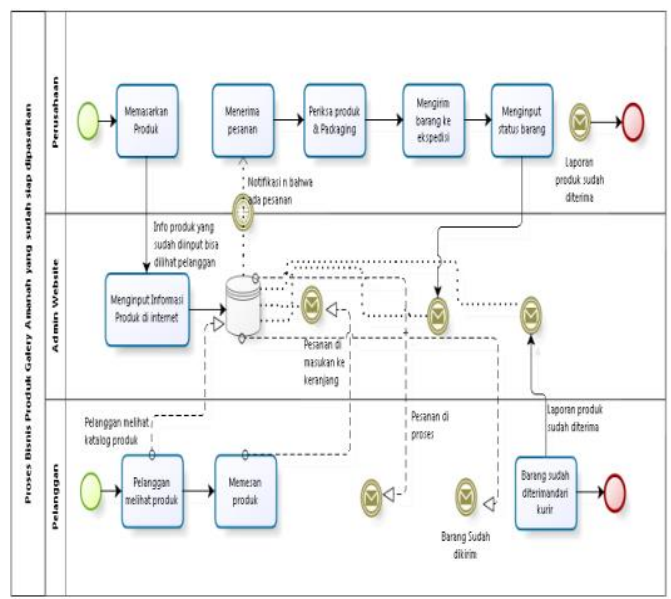

Gambar 6 Model as-is Penerimaan Order Galery Amanah 


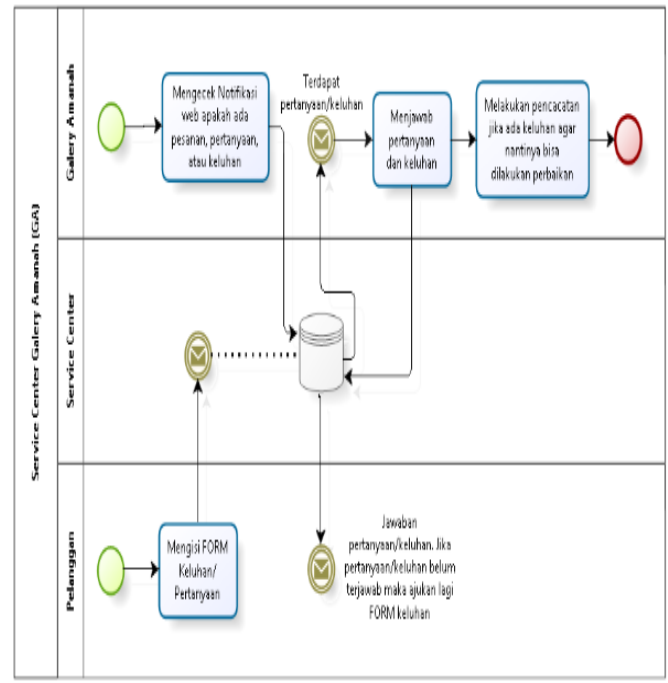

Gambar 7 Model as-is Penanganan Keluhan dan Pertanyaan Galery Amanah

Pada tahap analisis dilakukan analisis kesesuaian terhadap regulasi dan kelemahan yang terdapat pada proses bisnis fashion muslimah saat ini (as-is). Proses analisis ini mengacu pada proses model as-is dan reference model, analisis kesesuaian ini dilakukan untuk mengetahui apakah proses model $a s$-is sesuai dengan standar atau tidak.
Berdasarkan hasil observasi dan wawancara dengan owner, didapatkan hasil analisa kesesuaian proses bisnis as-is dengan standar operasional yang dapat dilihat pada Tabel 3.

\section{Proses Redesign}

Setelah didapatkan hasil tahap process analysis, maka kemudian pada tahap process redesign dibuat rekomendasi proses baru dengan cara memodelkan proses bisnis to-be dengan notasi BPMN.

Pada proses model as-is proses produksi, mulanya belum berdasarkan SOP dan tidak terdapat proses pemeriksaan bahan maka di process redesign ini akan diusulkan rekomendasi pada proses model to-be yang sudah disesuaikan dengan SOP. Model to-be proses produksi Galeri Amanah dapat dilihat pada Gambar 8 Model to-be Proses Produksi Pada Galery Amanah, Gambar 9 untuk Model to-be Penerimaan Order Galery Amanah, dan Gambar 10 Model to-be Penanganan Keluhan dan Pertanyaan Galery Amanah

Tabel 3 Analisis Aktivitas dan Kesesuaian Proses Bisnis Galery Amanah

\begin{tabular}{|c|c|c|c|}
\hline No & Aktivitas & Analisis & Kesesuaian \\
\hline 1 & Produksi & $\begin{array}{l}\text { Aktivitas ini merupakan } \\
\text { aktivitas yang dilakukan oleh } \\
\text { perusahaan dan merupakan } \\
\text { jenis aktivitas real value } \\
\text { added (RVA) karena } \\
\text { aktivitas ini dibutuhkan } \\
\text { untuk menghasilkan output } \\
\text { bagi pelanggan. Aktivitas ini } \\
\text { sangat berpengaruh kepada } \\
\text { proses bisnis, perusahaan } \\
\text { ataupun pelanggan. Namun } \\
\text { ada beberapa kendala yang } \\
\text { didapat yaitu belum adanya } \\
\text { SOP secara tertulis, pada } \\
\text { BPMN juga belum terdapat } \\
\text { pengendalian kualitas baik } \\
\text { pada bahan dan produk jadi. }\end{array}$ & $\begin{array}{l}\quad \text { Teknik Perbaikan : } \\
\quad \text { Standarisasi } \\
\text { Dengan menambahkan SOP } \\
\text { tentunya akan membuat } \\
\text { aktivitas ini lebih terarah dan } \\
\text { sesuai prosedur, sehingganya } \\
\text { tidak ada proses yang } \\
\text { tertinggal ataupun terlupakan. } \\
\text { SOP ini harus memenuhi } \\
\text { prinsip sesuai aturan } \\
\text { pemerintah pada } \\
\text { PERMENPAN PER/21/M- } \\
\text { PAN/11/2008. }\end{array}$ \\
\hline 2 & $\begin{array}{c}\text { Pengendalian } \\
\text { kualitas bahan } \\
\text { baku dan produk }\end{array}$ & $\begin{array}{l}\text { Aktivitas ini merupakan } \\
\text { aktivitas yang dilakukan oleh } \\
\text { perusahaan, dan termasuk } \\
\text { dalam business value added } \\
\text { (BVA) karena merupakan } \\
\text { proses pendukung agar }\end{array}$ & $\begin{array}{l}\text { Teknik Perbaikan: } \\
\text { Standarisasi } \\
\text { Proses standarisasi sangat } \\
\text { diperlukan dalam proses } \\
\text { pengendalian kualitas bahan }\end{array}$ \\
\hline
\end{tabular}




\begin{tabular}{|c|c|c|c|}
\hline & & $\begin{array}{l}\text { proses selanjutnya dapat } \\
\text { berjalan. Aktivitas ini } \\
\text { berpengaruh kepada } \\
\text { kepuasan pelanggan akan } \\
\text { produk yang ditawarkan } \\
\text { perusahaan, semakin tinggi } \\
\text { kepuasan pelanggan maka } \\
\text { akan semakin meningkatnya } \\
\text { permintaan. }\end{array}$ & $\begin{array}{l}\text { baku dan produk, hal tersebut } \\
\text { dilakukan agar kualitas produk } \\
\text { perusahaan tetap stabil dan } \\
\text { tidak ada reject. Maka dari itu } \\
\text { diperlukan form pengendalian } \\
\text { ataupun kebijakan antara } \\
\text { perusahaan dan subkontraktor } \\
\text { agar saling menguntungkan. }\end{array}$ \\
\hline 3 & Penanganan Order & $\begin{array}{l}\text { Aktivitas ini merupakan } \\
\text { aktivitas yang dilakukan oleh } \\
\text { perusahaan, dan termasuk } \\
\text { real value added (RVA) } \\
\text { karena berhubungan } \\
\text { langsung dengan pelanggan. } \\
\text { Aktivitas ini tidak memiliki } \\
\text { pengaruh terhadap produk, } \\
\text { akan tetapi mempermudah } \\
\text { pelanggan dan perusahaan } \\
\text { dalam aktivitas jual beli. }\end{array}$ & $\begin{array}{l}\quad \text { Teknik Perbaikan : } \\
\quad \text { Penyederhanaan } \\
\text { Aktivitas ini sudah berjalan } \\
\text { dengan baik dan sesuai } \\
\text { prosedur karena menggunakan } \\
\text { sebuah sistem informasi } \\
\text { berbasis web, hanya perlu } \\
\text { penyederhanaan agar aktivitas } \\
\text { ini makin efektif dan efisien. } \\
\text { Penyederhanaan ini nantinya } \\
\text { bisa dikonsultasikan dengan } \\
\text { web developer (pembuat web) } \\
\text { supaya didapat sistem } \\
\text { informasi yang lebih menarik, } \\
\text { efisien dan efektif bagi } \\
\text { perusahaan dan pelanggan. }\end{array}$ \\
\hline 4 & $\begin{array}{c}\text { Service Center/ } \\
\text { Penanganan } \\
\text { Keluhan } \\
\text { Pelanggan }\end{array}$ & $\begin{array}{l}\text { Aktivitas ini merupakan } \\
\text { aktivitas yang dilakukan oleh } \\
\text { perusahaan, dan termasuk } \\
\text { dalam busniness value added } \\
\text { (BVA). Aktivitas ini } \\
\text { berpengaruh terhadap } \\
\text { perusahaan walaupun tidak } \\
\text { secara langsung. Akan tetapi } \\
\text { aktivitas ini berpengaruh } \\
\text { pada hubungan perusahaan } \\
\text { dan pelanggan. }\end{array}$ & $\begin{array}{l}\text { Aktivitas ini sudah berjalan } \\
\text { dengan baik, hanya perlu } \\
\text { penyederhanaan agar aktivitas } \\
\text { ini berjalan lebih efisien dan } \\
\text { efektif. }\end{array}$ \\
\hline
\end{tabular}




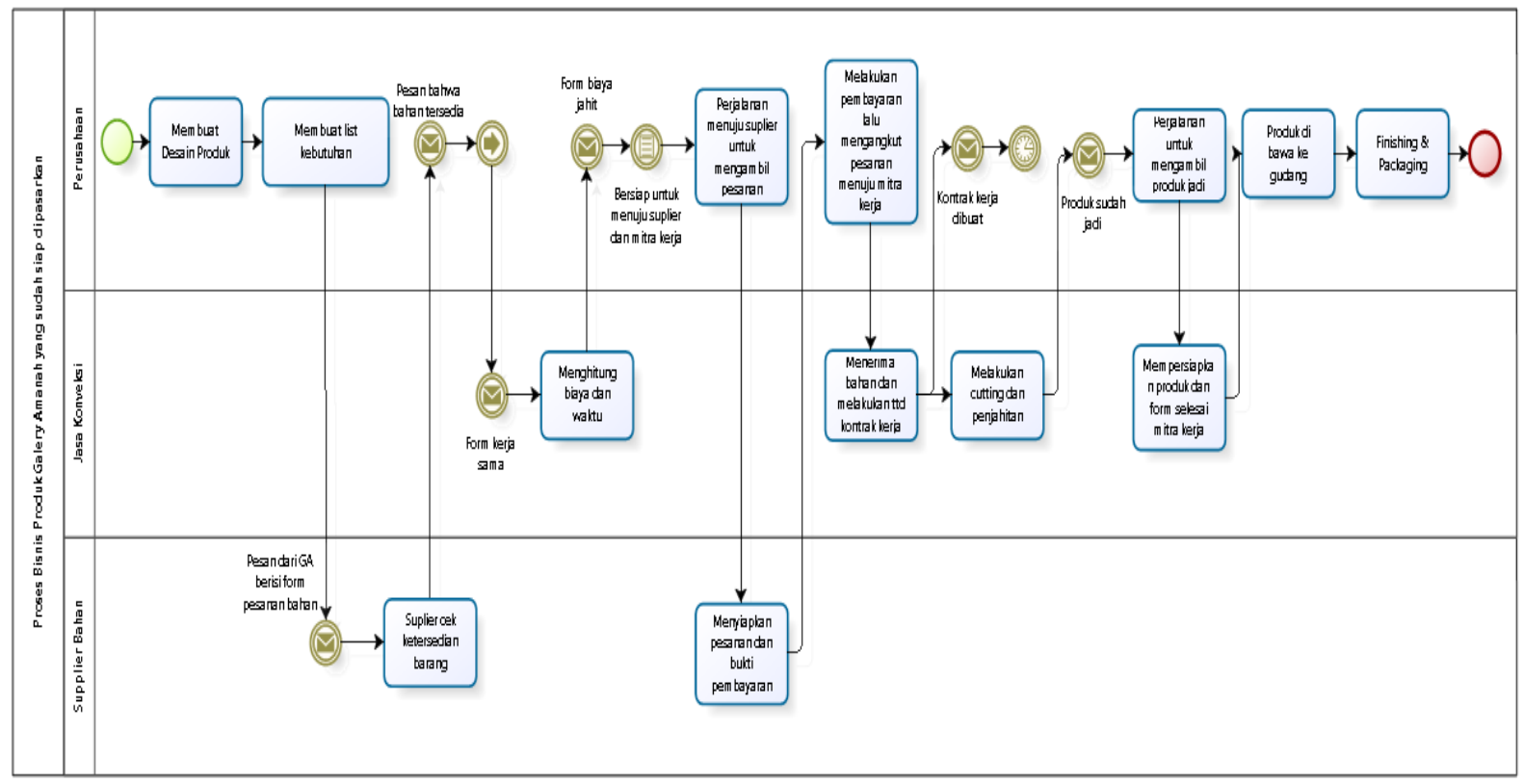

Gambar 8 Model to-be Proses Produksi Pada Galery Amanah

Berikut beberapa perbedaan yang terdapat pada model as-is dan model to-be, yaitu:

1. Pada model to-be notasi lane perusahaan terdapat beberapa penambahan aktivitas konfirmasi ketersediaan bahan baku, konfirmasi formulir biaya dari jasa konveksi, penambahan aktivitas pembuatan kontrak kerja dengan jasa konveksi dan aktivitas transportasi produk ke gudang "Galery Amanah".
2. Pada model to-be notasi lane jasa konveksi terdapat penambahan aktivitas pembuatan dan persetujuan formulir kerja sama dan biaya pengerjaan.

3. Pada model to-be notasi lane supplier bahan baku terdapat penambahan aktivitas yaitu aktivitas konfirmasi formulir pemesanan bahan baku, dan aktivitas pengecekan ketersediaan bahan baku sebelum dipesan.

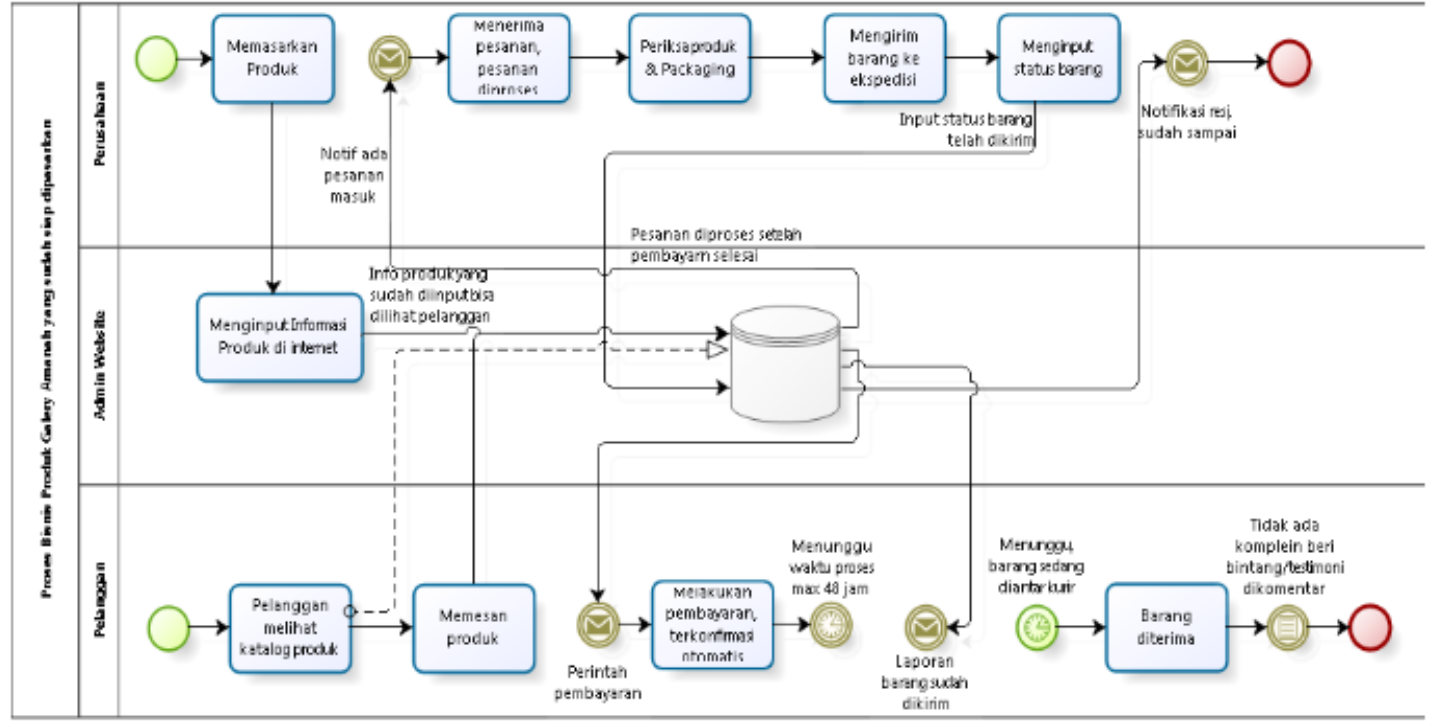

Gambar 9 Model to-be Penerimaan Order Galery Amanah

Berikut beberapa perbedaan yang terdapat pada model to-be Proses Penerimaan Order "Galery Amanah", yaitu:
1. Pada model to-be proses penerimaan order lane perusahaan, terdapat notifikasi berupa pesan status resi pengiriman. 

menggunakan Pendekatan Business Process Management (BPM)

2. Pada model to-be proses penerimaan order lane pelanggan, terdapat penambahan aktivitas rangkaian prosedur pembayaran dan juga proses komplain jika ada kekeliruan
3. Model to-be proses penerimaan order menjadi lebih jelas aliran datanya sehingga mempermudah untuk membuat desain website "Galery Amanah".

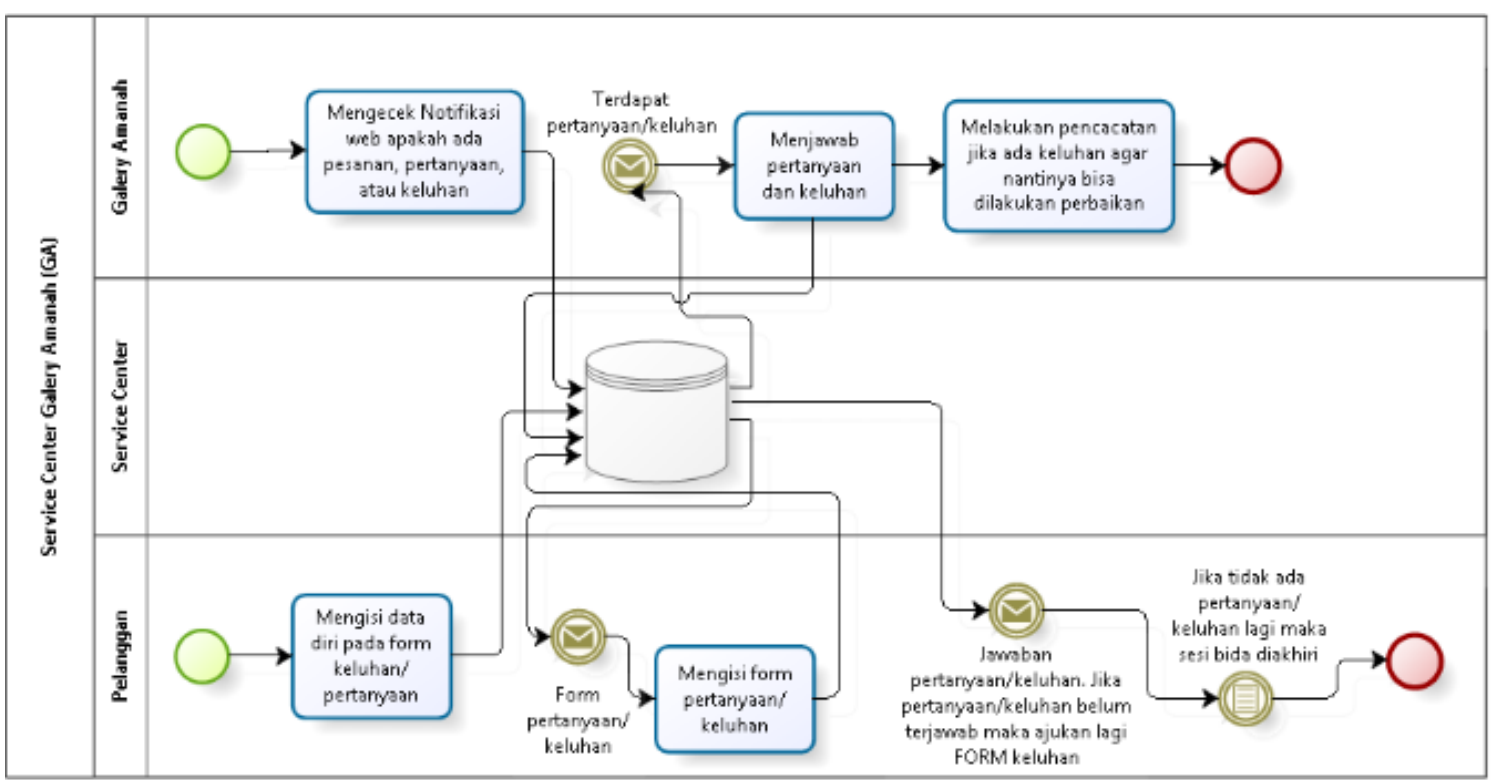

Gambar 10 Model to-be Penanganan Keluhan dan Pertanyaan Galery Amanah

Penambahan aktivitas pada model to-be penanganan keluhan pelanggan

1. Pada lane pelanggan terdapat penambahan yaitu pemisahan aktivitas pengisian data diri dan form pertanyaan, hal ini dilakukan agar proses lebih tersusun dan bisa melakukan beberapa kali proses tanya jawab tanpa mengulangi mengisi data diri.

2. Pada model to-be penanganan order, aktivitas ini hanya bisa diakses oleh pelanggan dan pihak "Galery Amanah" sehingga bisa terjadi percakapan yang interaktif.

3. Dalam sebuah sistem internet adanya standarisasi membuat seluruh proses lebih terdokumentasi dan dapat diakses dimanapun.

\section{KESIMPULAN DAN SARAN}

Berdasarkan hasil penjabaran, didapatkan kesimpulan dari penelitian ini. Berikut beberapa kesimpulan yang didapat dari hasil penelitian, yaitu: Berdasarkan perhitungan Break event point (BEP), Payback Perdiod (PP), Internal Rate of Return (IRR), Net Present Value (NPV), Profitability Index (PI) "Galery Amanah" layak untuk dijalankan, berdasarkan analisis aspek pasar dan pemasaran diketahui jika target pasar "Galery
Amanah" di Bekasi adalah sejumlah 832 orang. Dari hasil analisis SWOT diperoleh beberapa strategi alternatif untuk mempertahankan produk di pasar, diantaranya yaitu memperluas daerah pemasaran, melakukan banyak strategi promosi yang menarik, membuat desain/konsep produk yang menarik sesuai tema, melakukan analisis pasar agar PLC bertahan lebih lama, menentukan strategi bersaing, dan lain-lain, berdasarkan analisis aspek pesaing, berdasarkan hasil analisis Porter Five Force didapatkan hasil bahwa persaingan perusahaan bisnis fashion muslimah cenderung tinggi pada ancaman persaingan perusahaan sejenis, ancaman pendatang baru serta ancaman dari kekuatan tawar menawar pembeli, maka dari itu diperlukan strategi bersaing. Berikut beberapa strategi alternaif yang bisa digunakan yaitu: market development, differentiation, cost leadership, innovation dan alliance, berdasarkan analisis aspek hukum, perizinan yang dibutuhkan adalah SIUP (Surat Izin Usaha Perdagangan), TDP (Tanda Daftar Perusahaan) dan perusahaan harus memenuhi prinsip PP 80 Tahun 2019 mengenai Perdagangan Melalui Sistem Elektronik (PMSE), berdasarkan analisis aspek teknis/produksi didapatkan hasil bahwa lokasi, 
gudang, layout dan masalah teknis sudah sesuai. Sedangkan untuk masalah produk didapatkan beberapa alternatif kebijakan yaitu: (1) Analisis dari hasil penjualan, jika penjualan produk terdapat kenaikan maka jumlah produksi akan ditingkatkan. (2) Jika produk tersisa sekitar 20 set tiap jenisnya, perusahaan akan melakukan produksi lagi, berdasarkan analisis aspek finansial analisis profit margin $30 \%$, didapatkan nilai Payback Period yaitu 8 bulan, nilai NPV sebesar 18.507.692 dimana lebih dari nol, IRR yang diperoleh yaitu $14,6 \%$ dan lebih besar dari tingkat suku bunga yaitu $4 \%$, serta hasil perhitungan PI menunjukkan angka 1,47>1, berarti usaha Galery Amanah berdasarkan aspek finansial layak untuk dijalankan. Sedangkan dari hasil analisis aliran kas, "Galery Amanah" pertahunnya menghasilkan keuntungan sebesar Rp21.000.000, berdasarkan analisis menggunakan metode Business Process Management (BPM), didapatkan penambahan beberapa proses bisnis baru dan penyederhanaan proses bisnis. Model proses yang akan datang (to-be) sudah mengacu pada standarisasi proses bisnis dan proses produksi. Model to-be tersebut sudah selesai dilakuakan standarisasi dan penyederhanaan yang membuat model tersebut dapat diimplementasikan, dan Hasil analisis kelayakan bisnis fashion muslimah "Galery Amanah" yang telah dilakukan mendapat kesimpulan bahwa bisnis tersebut layak untuk dijalankan, sehingga tidak diperlukan analisis lanjut.

\section{DAFTAR PUSTAKA}

Center, A. P. \& Q. (2006). Process Classification Framework in Process Classification Framework. AQPC, 2006, p. 16.
Danang, S. (2012). Dasar Dasar Manejemen Pemasaran. Yogyakarta: CAPS.

Dumas, M., La Rosa, J., Mendling, \& Reijers, H. J. (2013). Fundamentals of Business Process Management. Berlin: Springer

Jakfar, K. (2010) Studi Kelayakan Bisnis, Edisi Kedua. Jakarta: Kencana Prenada Media

Lawler, J. P., \& Barber, H. H. (2013). Service Oriented Architecture SOA Strategy. Methodology, and Technology. vol. 53, no. 9. 2.Waluyo, M. (2010). Manajemen Perusahaan Industri. Sidoarjo: Dian Samudra.

Ningtiyas, R. K., Pulansari, F., Hayati, K. R., \& Anyar, G. (2018). Penerapan Business Process Management ( BPM ) ( Studi Kasus : Proses Bisnis Mengeksekusi dan Mengelola Rencana Penjualan di Divisi Niaga PT PJB Services ). Jurnal Teknologi, vol. 11, no. 1, pp. 65-71, 2018.Nugraha, D., Daningrum, V., Ariyadi, \& Fiqar, T. P. (2019). Pemodelan Proses Bisnis Penggajian pada PT. Bumi Sawindo Permai. Journal Ilmiah Teknologi Informasi (JUTI), vol. 17, pp. 12-20, 2019.

Setriani, S. E. (2013). Business Plan Sebagai Implementasi Kewirausahaan Pada Pembelajaran Ekonomi di SMA. Journal Dinamika Pendidikan, vol. VIII, no. 2, pp. 146-155, 2013.

Sulastri, L. (2016). Studi Kelayakan Bisnis untuk Wirausaha. LaGood's Publishing Group. 